\title{
OPTIMALISASI BAHASA: PENGGUNAAN BAHASA YANG BAIK, LOGIS, DAN SANTUN DI MEDIA MASSA
}

\author{
Syihaabul Hudaa \\ Sekolah Tinggi Ilmu Ekonomi Ahmad Dahlan, Indonesia \\ E-mail: hudaasyihaabul@gmail.com
}

\begin{abstract}
This study aims to study the language in mass media. The focus of this research is the usagee of language; unwell, illogical, and ignore the politeness in the language. The mass media offered a language that was inconsistent with the reader's expectations, so the text caused dissatisfaction of the reader. Nowadays, democracy grows in Indonesia. Language in mass media also was involved in freedom when it was delivered. So that, it caused of the neglect of the language aspect that should be the main point by the author. This study tells how the conventional media and be popular in public, by separated the use of good and correct Indonesian. Kind of this research is qualitative research, by making Kompas newspaper as research object.Researchers found some disregarding aspects of politeness in language such as: ignoring the facts, the title is not appropriate, the term is not appropriate and so forth. The optimization of language is expected to make everyone pay attention to write well and use the correct language. In addition, language rules and courtesy in language should be applied in writing the mass media.
\end{abstract}

Keywords: language optimization; mass media; reasonable; politeness

\begin{abstract}
Abstrak: Penelitian ini bertujuan mengkaji bahasa yang terdapat di dalam media massa. Fokus penelitian ini adalah penggunaan bahasa yang tidak baik, tidak logis, dan mengabaikan kesantunan dalam berbahasa. Media massa menyajikan informasi menggunakan bahasa yang disukai oleh penulisnya, sehingga berita di media massa seperti koran terkadang bersifat subjektif. Seiring demokrasi yang semakin berkembang di Indonesia, bahasa di media massa juga mengalami kebebasan dalam penyampaiannya. Akibatnya adalah pengabaian aspek kebahasaan yang seharusnya menjadi perhatian utama oleh penulisnya. Penelitian ini menyajikan bagaimana media massa konvensional dan dikenal publik, masih mengesampingkan penggunaan bahasa Indonesia yang baik dan benar. Penelitian ini tergolong ke dalam penelitian kualitatif, dengan menjadikan koran Kompas sebagai objek penelitian. Peneliti menemukan beberapa pengabaian aspek kesantunan dalam berbahasa seperti: mengabaikan fakta, judul tidak sesuai, istilah yang tidak tepat dan lain sebagainya. Pengoptimalisasian bahasa diharapkan mampu membuat semua pihak memerhatikan penulisan bahasa yang baik dan benar. Selain itu, kaidah kebahasaan dan kesantuanan dalam berbahasa perlu diaplikasikan dalam penulisan di media massa.
\end{abstract}

Kata Kunci: optimalisasi bahasa; media massa; kelogisan; kesantunan

Permalink/DOI: http:/ /dx.doi.org/10.15408/dialektika.v5i1.5953 


\section{Pendahuluan}

Media massa merupakan suatu bahan bacaan yang sering menjadi sorotan publik. Sebagai suatu bentuk bahan bacaan publik, media massa memiliki peranan penting dalam penggunaan bahasa yang baik dan benar. Baik diartikan sebagai sesuai dengan konteks penggunannya, sedangkan benar diartikan sesuai dengan kaidah bahasa itu sendiri. Untuk itu, seorang penulis perlu memperhatikan penggunaan bahasanya.

Fraser dan Nolem dalam Eelen menyebut bahwa kesantunan menjadi suatu aspek yang perlu diperhatikan dalam berbahasa. Sebaliknya, pengabaian aspek kesantunan menjadi pelanggaran dalam suatu percakapan. ${ }^{1}$ Penerapan kesantunan dalam berbahasa perlu diperhatikan, terutama di media massa yang banyak dibaca oleh masyarakat. Hal tersebut dilakukan agar pembaca awam mampu mengadopsi bahasa yang digunakan sebagai bahasa sehari-harinya.

Bahasa Indonesia dalam media massa sering kali menggunakan kata yang kasar atau bentuk pengasaran (disfemisme) dan hal tersebut merupakan kebalikan dari bentuk penghalusan (eufemisme). ${ }^{2}$ Penggunaan bahasa tersebut bertujuan membuat suatu judul menjadi lebih menarik, atau menjadikan suatu berita menjadi lebih sederhana. Akan tetapi, hal tersebut justru membuat pembaca menjadi tidak puas akan isi beritanya. Media massa berperan penting dalam menyuarakan aspirasi masyarakat. Kebebasan berpendapat inilah yang kemudian menjadi salah satu sebab media massa mengabaikan aspek kesantunan dalam berbahasa. Penulis di media massa terkadang tidak mengaplikasikan kaidah penulisan yang baik dan benar. Misalnya saja suatu media menggunakan istilah yang identik dengan binatang untuk menamai suatu organisasi atau objek lainnya seperti manusia.

Penggunaan bahasa yang tidak tepat di dalam suatu media massa, sering kali menjadi pemicu suatu konflik. Hal tersebut sering ditemukan menjelang pilkada atau pilpres dengan munculnya ujaran kebencian di media sosial dan media massa. Ujaran ini dimuat di media massa berdasarkan keberpihakan seseorang, sehingga berita dibuat subjektif. Pembaca nantinya akan merespon tulisan yang dimuat di media massa. Setelah itu, pembaca kritis tentunya akan menganalisis pesan yang terdapat di dalam media massa tersebut. Jika suatu

\footnotetext{
${ }^{1}$ Gino Eelen, Kritik Teori Kesantunan, (Surabaya: Airlangga University Press, 2006), h. 15.

${ }^{2}$ Kasmansyah, "Mengkaji Ulang Media Massa dalam Pembinaan dan Pengembangan Bahasa Indonesia” dalam Risalah Kongres BahasaVIII, (Jakarta: Pengembangan dan Pembinaan Bahasa Kementerian Pendidikan dan Kebudayaan, 2011), h. 731.
} 
tulisan menyinggung suatu pihak, maka pihak yang tersinggung akan merasa dirugikan. Kondisi ini, tentu saja sangat memprihatinkan, ketika seharusnya media massa berperan mendidik pembaca untuk bersikap lebih baik.

Kebebasan dalam menulis sering kali dijadikan alasan oleh penulis dalam menuliskan karyanya. Hal tersebut menjadikan seorang penulis bebas memilih bahasa yang digunakan dalam tulisannya. Pengabaian kaidah kebahasaan inilah yang kemudian menjadikan suatu media massa tidak berperan optimal dalam membina dan mendidik masyarakat. Tentu saja hal tersebut bertolak belakang dari nilai esensi media massa.

Kesantunan dalam berbahasa merupakan suatu kaidah yang dapat meminimalisasi terjadinya konflik di dalam pergaulan. ${ }^{3}$ Pengabaian kaidah kebahasaan, mampu menyebabkan dekadensi bagi pembacanya. Hal tersebut dikarenakan bahan bacaan merupakan suatu media yang terintegrasi dengan bidang ilmu pengetahuan. Karena bahasa, merupakan suatu bentuk tulisan yang memperhatikan aspek logis dan etis yang tercipta dari realitas sosial. Untuk itu, media massa seharusnya menyajikan suatu berita yang informatif, baik, logis, dan tidak mengabaikan kesantunan dalam berbahasa.

Peneliti masih menemukan beberapa tulisan di media massa yang belum memperhatikan aspek kesantunan dalam berbahasa, misalnya saja membuat redaksi berita yang tidak sesuai dengan isi berita di dalamnya. Akibatnya, tulisan yang disajikan dapat menimbulkan konflik baru. Melalui tulisan ini, peneliti ingin menyajikan gagasan terkait pengoptimalisasian bahasa yang terdapat di dalam media massa. Hal tersebut bertujuan untuk mengurangi atau meminimalisasi pengabaian aspek kebahasaan. Optimalisasi bahasa dalam tulisan ini menerapkan rancangan konstruksi bahasa yang baik, logis, dan santun. Penelitian ini difokuskan pada koran Kompas tanggal 18 Juli 2017.

\section{Landasan Teori}

\section{Baik}

Arifin dan Tasai mendefinisikan baik sebagai penggunaan bahasa Indonesia yang sesuai dengan konteksnya. ${ }^{4}$ Artinya, seorang pengguna bahasa tidak hanya harus menyesuaikan dengan lawan berbicaranya melainkan juga dengan konteks ketika berbicara. Terkait dengan bahasa jurnalistik, Dewabrata

${ }^{3}$ Abdul Chaer, Kesantunan Berbahasa, (Jakarta: Rineka Cipta, 2010), h. 34.

${ }^{4}$ E. Zainal Arifin dan S. Amran Tasai, Cermat Berbahasa Indonesia, (Jakarta: Akademika Pressindo, 2010), h. 25. 
dalam Suhaemi dan Nasrullah mengemukakan bahwa "baik" dalam ragam jurnalistik ditandai dengan kalimat-kalimat yang lancar sampai akhir, mudah dicerna, merakyat, dan akrab di telinga masyarakat. ${ }^{5}$ Sementara itu, Rosihan Anwar dalam Suhaemi dan Nasrullah mengemukakan bahwa bahasa pers haruslah jelas, singkat, padat, lancar, lugas, dan menarik. ${ }^{6}$ Dapat disimpulkan bahwa bahasa yang baik digunakan di media massa adalah bahasa yang mudah dipahami, lugas, tegas, mudah dicerna, dan dimengerti oleh semua kalangan masyarakat.

\section{Logis}

Arifin dan Tasai mengemukan bahwa logis merupakan suatu hal yang dapat diterima dengan akal. ${ }^{7}$ Artinya suatu kalimat yang ditulis mampu dinalarkan sesuai dengan makna dan tujuan penulisannya. Di media massa, aspek kelogisan menjadi suatu hal yang perlu diperhatikan. Hal tersebut dikarenakan media massa merupakan media yang umum dibaca oleh pelbagai elemen masyarakat.

\section{Santun}

Santun merupakan suatu hal yang perlu diperhatikan dalam berbahasa. Leech mengemukakan dalam berbahasa perlu memperhatikan ujaran yang digunakan. Hal tersebut bertujuan untuk meminimalisasi kerugian pada orang lain. ${ }^{8}$ Santun dalam media massa merupakan suatu hal yang perlu diperhatikan oleh setiap penulis. Tujuannya agar tidak ada pihak yang dirugikan dari redaksi yang digunakan. Untuk itu, aspek kesantunan dalam berbahasa perlu dioptimalisasi penggunaannya dalam setiap kalimat.

\section{Metode}

Penelitian ini merupakan bentuk penelitian kualitatif. Penelitian kualitatif berfokus pada fenomena sosial dan pemberian suara pada perasaan dan persepsi dari partisipan di bawah studi. ${ }^{9}$ Penelitian ini lebih banyak mengumpulkan data berupa kata-kata, gambar, daripada angka-angka. Hasil penelitian ini dipaparkan secara deskriptif dengan memaparkan hasil temuan penelitian yang sudah dianalisis.

\footnotetext{
${ }^{5}$ Suhaemi dan Ruli Nasrullah, Bahasa Jurnalistik, (Jakarta: Lembaga Penelitian UIN, 2009), h. 5.

${ }^{6}$ Suhaemi dan Ruli Nasrullah, Bahasa Jurnalistik...., h. 6.

${ }^{7}$ E. Zainal Arifin dan S. Amran Tasai, Cermat Berbahasa Indonesia...., h. 106.

${ }^{8}$ Geoffrey Leech, Prinsip-Prinsip Pragmatik, (Jakarta: UI Press, 2015), h. 206.

${ }^{9}$ Emzir, Metode Penelitian Kualitatif: Analisis Data, (Jakarta: Rajawali Pers, 2012), h. 2.
} 
Penelitian kualitatif lebih berkonsentrasi pada proses daripada dengan hasil atau produk. ${ }^{10}$ Dengan demikian, penelitian kualitatif menjadikan seorang peneliti memiliki kebebasan dalam menganalisis suatu data. Selain itu, penelitian kualitatif menitikberatkan analisis makna yang terdapat di dalam suatu bahasa.

\section{Pembahasan}

Dalam penulisan di media massa, laras yang digunakan tentu saja laras bahasa jurnalistik. Laras jurnalistik ditandai dengan pemadatan atau penyederhanaan struktur sintaksis. Penyederhanaan itu berupa penghilangan konjungtor tertentu atau butir leksikal tertentu. ${ }^{11}$ Laras jurnalistik tentu saja memerlukan ragam tulisan dalam penyampaiannya. Ragam tulis perlu lebih terang dan lebih lengkap daripada ragam lisan. Fungsi-fungsi gramatikal dalam ragam lisan harus nyata, karena ragam tulis tidak mewajibkan orang kedua berada di depan pembicara. ${ }^{12}$

Teks dimaksudkan untuk merepresentasikan makna tuturan seseorang yang disampaikan dalam bentuk tertulis. ${ }^{13}$ Tentu saja, suatu teks harus mampu merealisasikan maksud yang disampaikan oleh penuturnya. Proses berbicara maupun menulis, seseorang perlu memerhatikan kaidah bahasa yang baik dan benar. Baik berarti sesuai dengan konteksnya, dan benar sesuai dengan kaidah bahasa yang ada. ${ }^{14}$

\section{Baik}

\section{Judul Tidak Merepresentasikan Fakta}

Judul dalam media massa sering kali mengabaikan isi. Judul dibuat seakan memuat isi yang luar biasa, tetapi setelah pembaca membaca tulisan tersebut, isinya tidak sesuai ekspektasi pembaca. Seperti halnya yang sudah dibahas di landasan teori, suatu bahasa jurnalistik haruslah lugas, tegas, dan mudah dipahami. Leech mengemukakan bahwa suatu teks seharusnya disampaikan

\footnotetext{
${ }^{10}$ Emzir, Metode Penelitian Kualitatif..., h. 3.

${ }^{11}$ Mulyadi Eko Purnomo, "Bahasa Media Massa: Laras Bahasa Jurnalistik yang Perlu Dikembangkan” dalam Risalah Kongres Bahasa Indonesia VIII, (Jakarta: Pengembangan dan Pembinaan Bahasa Kementerian Pendidikan dan Kebudayaan, 2011), h. 708.

${ }^{12}$ E. Zainal Arifin dan S. Amran Tasai, Cermat Berbahasa Indonesia...., h. 19.

${ }^{13}$ Gillian Brown dan George Yule, Analisis Wacanaterj. I. Soetikno, (Jakarta: Gramedia Pustaka Utama, 2010), h. 6

${ }^{14}$ Hasan Alwi dkk, Tata Bahasa Baku Bahasa Indonesia, (Jakarta: Balai Pustaka, 2003), h. 20.
} 
dengan jelas dan mudah dipahami. ${ }^{15}$ Tujuannya tentu saja agar pembaca mendapatkan suatu hal yang sesuai dengan apa yang dia baca. Berikut contoh analisis judul yang tidak menggambarkan fakta.

1. Harapan pada 9 Negarawan (Kompas, 18 Juli 2017).

Pernyataan pada judul di atas tidak menggambarkan fakta. Kata negarawan diartikan sebagai orang yang memimpin politik secara taat atas menyusun kebijakan negara dengan visi mengelola negara secara bijaksana dan berwibawa. ${ }^{16}$ Isi berita tersebut menjelaskan terpilihnya Arief Hidayat sebagai ketua Mahkamah Konstitusi dan belum mengelola negara. Selain itu, konteks kata 9 negarawan tidak sesuai, karena isi berita tersebut menjelaskan siapa Arief Hidayat. Jika kalimat tersebut bertuliskan 'harapan', maka isi beritanya harus memasukkan opini publik terhadap 9 orang yang berada di Mahkamah Konstitusi.

2. Erdogan Semakin Kuat Berkuasa (Kompas, 18 Juli 2017).

Isi berita ini tidak menjelaskan kekuatan kekuasaan Erdogan. Secara keseluruhan, isi berita ini memuat kudeta yang terjadi selama masa pemerintahan Erdogan di Turki. Berita yang dimuat di koran ini menjelaskan bagaimana kudeta terjadi selama pemerintahan Erdogan dan menelan lebih dari 250 korban jiwa. Selain itu, tulisan ini memuat bagaimana Erdogan menjatuhkan hukuman kepada mereka yang melakukan kudeta. Sebaliknya, harapan pembaca mengenai kekuatan Erdogan dalam berkuasa belum ditemukan. Misalnya, Erdogan semakin kuat berkuasa artinya tidak ada lagi kudeta di negaranya.

3. UE Meminta Hak Warga Dibahas Rinci (Kompas, 18 Juli 2017).

Berita ini tidak sesuai dengan isi, karena yang dibahas dalam berita ini adalah masalah perdagangan Uni Eropa dan proses 'Brexit'. Selain berbicara tentang perdagangan dan 'Brexit', berita ini sepenuhnya membahas bagaimana memajukan Uni Eropa, bukan membahas tentang hak warga. Mengacu kepada judul tersebut, seharusnya yang dibahas dalam pertemuan tersebut adalah 'hak warga'. Dengan demikian, antara judul dan isi berita ini tidak sesuai.

\footnotetext{
${ }^{15}$ Geoffrey Leech, Prinsip-Prinsip Pragmatik..., h. 153.

${ }^{16}$ Badan Pengembangan dan Pembinaan Bahasa, KBBI Daring V, Diakses tanggal 04 Juli 2018.
} 
4. Pesta Diskon untuk Genjot Penjualan (Kompas, 18 Juli 2017).

Kata pesta diskon, artinya memberikan diskon pada segala barang yang dijual dalam jumlah yang besar. Kata tersebut tergolong gaya bahasa hiperbola yang bertujuan menarik minat pembeli. Akan tetapi, peggunaan kata 'pesta diskon' di sini terlalu berlebihan, karena barang yang diberikan diskon hanya beberapa barang, dan dengan harga khusus Rp72.000,00. Tentu saja hal tersebut tidak akan sesuai dengan ekspektasi pembaca dan pembelinya kelak. Dengan demikian kata pesta diskon tidak sesuai dengan isinya.

5. Polisi Bongkar Kapal Wanderlust (Kompas, 18 Juli 2017).

Judul berita ini juga tidak menggambarkan isinya. Isi berita ini memuat polisi yang sedang meneliti jalur kapal Wanderlust yang dipakai untuk menyelundupkan 1 ton narkoba. Kata bongkar, diartikan sebagai angkat, turunkan, tentang barang dari mobil dan lain sebagainya. Akan tetapi, jika dicermati redaksi kalimat yang digunakan yaitu mengacu kepada pembongkaran kapal. Seharusnya, kalimat tersebut ditambahkan kata 'isi', sehingga menjadi 'Polisi Bongkar Isi Kapal Wanderlust'. Jika redaksi kalimatnya seperti yang tertera di koran, berarti polisi membongkar kapal tersebut secara keseluruhan, hingga yang tersisa hanya kerangka kapal. Akan tetapi, dalam isi berita ini yang dilakukan polisi hanya mengeluarkan mesin kapal, tanpa membongkar seperti yang tertera di judul.

6. Main hingga Usia 40 Tahun (Kompas, 18 Juli 2017)

Berita ini sedang membicarakan seorang Roger Federer yang masih main tenis hingga usia 35 tahun 344 hari. Dengan demikian, judul di atas tidak sesuai karena usia Roger Federer masih 35 tahun 344 hari. Artinya, judul tersebut dengan usia Federer yang sebenarnya belumlah sesuai. Penambahan tahun yang dibuat, merupakan bentuk penyimpangan dari berita yang sebenarnya. Karena saat menjuarai Wimbledon, Federer belum berusia 40 tahun. Redaksi berita tersebut tentu saja dapat dikatakan benar, apabila Federer saat menjuari Wimbledon sudah berusia 40 tahun.

7. AC Milan Pilih Morata (Kompas, 18 Juli 2017)

Judul ini tidak sesuai dengan isi berita, karena yang dibahas di dalamnya tentang Bonuci yang kelak akan dipensiunkan AC Milan. Mengacu kepada judul tersebut, seharusnya AC Millan memfokuskan membahas 
Morata yang notabenenya digadang-gadang menjadi pengganti Bonuci. Ketidaksesuaian judul dengan isinya merupakan bentuk penyimpangan, karena pembaca tentunya mengharapkan pembahasan mengenai Morata, seperti teknik dan kemampuan yang dimilikinya.

\section{Ketidakjelasan Struktur Frasa dan Klausa}

1. Adanya bukaan yang cukup banyak akan memberikan aliran udara sehingga temperatur ruangan tetap ideal (Kompas, 18 Juli 2017). Jika dicermati, kalimat ini tidak jelas dan tidak logis. 'Adanya bukaan' tidak diikuti dengan penjelas dari kata tersebut, sehingga mengakibatkan strukturnya menjadi tidak jelas. Penjelas dari kata 'bukaan' tidak ditemukan, sehingga membuat strukturnya menjadi tidak jelas dan berdampak pada tidak logisnya suatu pernyataan. Selain itu, kalimat tersebut tidak memperhatikan penggunaan tanda baca.

2. Judul "Erdogan Semakin Kuat Berkuasa", sedangkan dalam pengantar beritanya 'Ia semakin berkuasa dan kuat'. (Kompas, 18 Juli 2017). Dalam berita ini, terdapat penyimpangan struktur penulisan. Di mana judul tersebut tidak berhubungan dengan isinya. Dalam kalimat "Erdogan Semakin Kuat Berkuasa” memiliki arti kekuasaannya yang semakin kuat. Akan tetapi, di dalam isinya bertuliskan 'Ia semakin berkuasa dan kuat' berarti kata ini mengalami perubahan makna dengan masuknya 'dan' sebagai pemisah katanya.

\section{Ketiadaan Penggunaan Sufiks}

1. Saya akan melihat kelembagaan KPK berdasar pendapat ahli... (Kompas, 18 Juli2017). Kata yang tepat adalah 'berdasarkan', karena 'berdasarkan' diartikan 'memakai sebagai dasar'.

\section{Logis}

\section{Judul Dibuat Berlebihan}

Dalam suatu media, sering kali judul dibuat berlebihan hingga menimbulkan nuansa kekerasan. Akan tetapi, isi berita tidak seperti yang dituliskan pada judul. Hiperbola adalah semacam gaya bahasa yang mengandung suatu pernyataan yang berlebihan, dengan membesarkan suatu hal. ${ }^{17}$ Teks merupakan suatu alat untuk menyampaikan pesan. ${ }^{18}$ Oleh karena

\footnotetext{
${ }^{17}$ Gorys Keraf, Diksi dan Gaya Bahasa, (Jakarta: Gramedia Pustaka Utama, 2010), h. 135.
} 
itu, pemilihan diksi dalam suatu kalimat seharusnya dapat lebih diperhatikan. Beberapa kalimat di bawah ini, menggunakan diksi yang kurang tepat, sehingga berdampak pada suatu unsur negatif. Sebagai contoh kata 'setiap hari, empat sepeda motor dicuri di Palu'. Hal ini tentu saja memunculkan stigma kota Palu. Selain judul tersebut, contoh judul di bawah ini juga mengandung unsur berlebihan.

1. Jangan Bunuh KPK (Kompas, 18 Juli 2017).

2. Rokok Ikut Membuat Miskin (Kompas, 18 Juli 2017).

3. Setiap Hari, Empat Sepeda Motor Dicuri di Palu (Kompas, 18 Juli 2017).

\section{Judul Menggunakan Istilah yang Tidak Tepat}

Dalam suatu penulisan, istilah menjadi penguat makna yang akan disampaikan. Penggunaan istilah berkaitan erat dengan diksi. Dengan demikian, penggunaan diksi dalam suatu istilah akan memengaruhi makna yang disampaikan dalam suatu tulisan.

1. Menggunakan istilah yang memiliki makna yang sama, sehingga menimbulkan ketidakefektifan kalimat (muncul redudansi makna). Tanpa menggunakan kata 'gurita' pun sudah jelas maknanya bahwa kata "aliran" memiliki makna "bergerak ke beberapa arah". Sebaiknya di media massa menghindari kata yang memiliki makna pengulangan (redudansi makna) seperti di bawah ini.

- Gurita Aliran Dana Proyek KTP Elektronik (Kompas, 18 Juli 2017).

2. Keambiguan judul.

- Pertumbuhan Beri Ruang Reformasi (Kompas, 18 Juli 2017). Pertumbuhan di sini tidak ditulisakan secara jelas, apa yang tumbuh, sehingga mampu memberikan ruang untuk reformasi. Karena pertumbuhan masih bersifat umum.

- PTS Didorong Bergabung (Kompas, 18 Juli 2017). Kalimat di sini mengandung unsur ambiguitas. Apakah PTS diminta menjadi satu, dalam arti membentuk PTS baru dari beberapa PTS, atau

\footnotetext{
${ }^{18}$ Geofferey Leech, Prinsip-Prinsip Pragmatik...., h. 93
} 
diminta bekerja sama. Sebaiknya kalimat tersebut diganti dengan istilah yang konvensional yaitu 'merger'.

- Sekolah Laut untuk Antisipasi Bencana (Kompas, 18 Juli 2017). Kalimat ini mengabaikan penggunaan kalimat efektif. Sekolah Laut, dapat diartikan sekolah yang ada di laut, atau sekolah yang mengajarkan tentang ilmu kelautan.

- Dicari, Dua Pemuda untuk Cetak Mimpi di Sepak Bola Dunia (Kompas, 18 Juli 2017). Penggunaan kata 'dicari' tidaklah tepat berada di awal kalimat, karena konteks kata 'dicari' untuk merepresentasikan kehilangan. Artinya, jika 'Dicari, Dua Pemuda...' dapat diartikan dua pemuda itu sudah ada sebelumnya, dan kini menghilang.

- Meningkatkan Daya Tahan (Kompas, 18 Juli 2017). Kalimat judul ini juga tidak memperhatikan kelengkapan kalimatnya. Dalam judul ini, pembaca tidak mampu melihat hubungan judul dengan isi, karena judulnya dibuat menggantung.

- Kelas Menengah Menopang Pertumbuhan (Kompas, 18 Juli 2017). Kalimat di samping mengabaikan aspek kelogisan dalam berbahasa. Kata 'menopang' tidak logis dikatakan kepada mereka yang berada di tingkat ekonomi menengah. Pembaca yang tidak cermat, tentu menilai kata 'kelas' merujuk kepada kelas dalam makna denotasi. Untuk itu, penggunaan kata tersebut dapat diganti menjadi Ekonomi Menengah Membantu Pertumbuhan Pembangunan.

\section{Kalimat yang Tidak Baik}

1. ...abai memenuhi asas keadilan dan kesetaraan dalam aspek keterwakilan. (Kompas, 18 Juli 2017). Kata 'abai' diartikan sebagai tidak dipedulikan, tidak dikerjakan baik-baik, dan tidak dipentingkan. Selain itu, kata 'abai' dapat diartikan sebagai lalai. Jika kata tersebut kita cermati, kata tersebut tidak memerlukan kata memenuhi. Baiknya kata tersebut diberikan imbuhan, menjadi '...mengabaikan asas keadilan dan kesetaraan dalam aspek keterwakilan’.

2. Biaya politik tinggi ini kerap menjerumuskan mereka pada korupsi saat sudah menjabat. (Kompas, 18 Juli 2017). Kalimat tersebut tidak 
memperhatikan kalimat yang baik. Kalimat ini dapat dikatakan suatu kalimat yang ambigu, 'biaya politik tinggi' diartikan biaya politik yang tinggi, atau biaya (pengeluaran) politik tinggi (unsur nama). Akan tetapi, dilihat dari keseluruhan kalimatnya, jelas bahwa yang disampaikan adalah biaya politik yang mahal. Akan tetapi, masalah di sini sudah jelas yaitu biaya yang mahal akan berdampak pada korupsi, jadi bukan menjerumuskan seseorang. Kata menjerumuskan tepat digunakan apabila seseorang tidak tahu dampak dan akibat dari tindakannya.

\section{Santun}

\section{Kalimat Menggunakan Istilah Binatang}

1. Hal itu berbuntut pada aksi boikot politik dan ekonomi disertai sejumlah tuduhan. (Kompas, 18 Juli 2017). Kata 'berbuntut' mengacu kepada binatang. Penggunaan kata ini tidak sesuai dengan kaidah bahasa, karena melanggar kesantunan dalam berbahasa. Kata 'berbuntut' merupakan kata yang melekat pada binatang. Kata tersebut tidak tepat berada pada istilah ekonomi atau politik. Selain itu, kata tersebut memiliki makna negatif karena 'kelanjutannya' tidak diinginkan terjadi. Kata tersebut dapat diganti dengan kata 'berdampak' atau 'berakibat' .

2. Aku pikir usia itu merayap perlahan dan tiba-tiba saja sudah berulang tahun ke-50. (Kompas, 18 Juli 2017). Kata 'merayap' jika diartikan memiliki arti berkerumun seperti rayap; bergerak maju dengan tangan dan kaki serta badan bertumpu ke tanah. Penggunaan kata 'merayap' tidaklah tepat dalam kalimat tersebut, karena kata tersebut identik dengan binatang. Selain identik dengan binatang, kata 'merayap' (bergerak perlahan) tidak tepat karena di depan kata tersebut sudah ada kata 'perlahan'.

\section{Diksi yang Tidak Tepat}

1. ...bisa menjadi dasar bahwa benar adanya kongkalikong dan bancakan uang dari proyek tersebut. (Kompas, 18 Juli 2017). Kata 'bancakan' memiliki arti selamatan, kenduri, atau hidangan yang disediakan dalam selamatan. Makna yang terdapat di dalamnya bersifat positif, sedangkan dalam kata 'bancakan uang proyek' memiliki makna yang negatif.

2. Salah satu kunci untuk melihat "jenis kelamin" KPK adalah teori pemisahan kekuasaan. (Kompas, 18 Juli 2017). Penggunaan kata “jenis kelamin' sebagai metafora tidaklah tepat, karena KPK bukanlah makhluk 
hidup. Selain itu, berita ini dimuat di media massa konvensional yang dapat dibaca siapa saja. Pembaca awam tentu saja memiliki pemikiran negarif terhadap berita ini. Diksi ini juga mengarah kepada konteks makna yang negatif dan melanggar norma kesantunan. Untuk itu, kata tersebut dapat diganti dengan 'keberanian' 'sikap' dan kata lainnya.

3. ...kemudian sudah ada untuk jalur bagi saudara kita yang disabilitas. (Kompas, 18 Juli 2017). Kata 'disabilitas' tidaklah tepat digunakan untuk menyatakan kekurangan yang terdapat pada orang lain. Karena saat ini sudah ada padanan kata yang lebih halus, yaitu difabel. Karena 'disabilitas' merupakan suatu bentuk kata transliterasi dari bahasa Inggris ke bahasa Indonesia.

\section{Simpulan}

Berdasarkan analisis yang dilakukan oleh peneliti pada koran Kompas, 18 Juli 2017, ditemukan beberapa aspek pengabaian kebahasaan. Kesalahan itu meliputi kesalahan penggunaan judul, di antaranya: (1) judul yang tidak merepresentasikan fakta, (2) judul yang dibuat berlebihan, (3) judul menggunakan istilah tidak tepat. Selain pada judul, ditemukan juga kesalahan dalam penulisan kalimat yaitu terdapat di dalam koran Kompas. Kesalahan tersebut di antaranya meliputi: (1) kalimat yang tidak baik, (2) kalimat yang menggunakan istilah binatang, (3) kalimat dengan ketidakjelasan struktur, (4) kalimat dengan diksi yang tidak tepat, (5) dan terakhir kalimat dengan ketidaklengkapan, yaitu ketiadaan penggunaan sufiks.

Dengan demikian, dapat disimpulkan bahwa pengoptimalisasian bahasa dalam sebuah media akan mampu membuat suatu media massa menjadi lebih logis, santun, dan baik. Dengan begitu, media massa dapat berperan aktif dalam mendidik dan membina pembacanya menjadi lebih santun dalam berbahasa.

\section{Daftar Pustaka}

Alwi, Hasan dkk. Tata Bahasa Baku Bahasa Indonesia. Jakarta: Balai Pustaka, 2003.

Arifin, E. Zainal dan S. Amran Tasai.Cermat Berbahasa Indonesia. Jakarta: Akademika Pressindo, 2010.

Badan Pengembangan dan Pembinaan Bahasa. KBBI Daring V. Diakses tanggal 04 Juli 2018. 
Brown, Gillian dan George yule. Analisis Wacana terj. I. Soetikno. Jakarta: Gramedia Pustaka Utama, 2010.

Chaer, Abdul. Kesantunan Berbahasa. Jakarta: Rineka Cipta, 2010.

Eelen, Gino. Kritik Teori Kesantunan. Surabaya: Airlangga University Press, 2006.

Emzir. Metode Penelitian Kualitatif: Analisis Data. Jakarta: Rajawali Pers, 2012.

Kasmansyah. "Mengkaji Ulang Media Massa dalam Pembinaan dan Pengembangan Bahasa Indonesia" dalam Risalah Kongres BahasaVIII. Jakarta: Pengembangan dan Pembinaan Bahasa Kementerian Pendidikan dan Kebudayaan, 2011.

Keraf, Gorys. Diksi dan Gaya Bahasa. Jakarta: Gramedia Pustaka Utama, 2010.

Leech, Geoffrey. Prinsip-Prinsip Pragmatik. Jakarta: UI Press, 2015.

Purnomo, Mulyadi Eko. "Bahasa Media Massa: Laras Bahasa Jurnalistik yang Perlu Dikembangkan” dalam Risalah Kongres Bahasa Indonesia VIII. Jakarta: Pengembangan dan Pembinaan Bahasa Kementerian Pendidikan dan Kebudayaan, 2011.

Suhaemi dan Ruli Nasrullah. Bahasa Jurnalistik. Jakarta: Lembaga Penelitian UIN Jakarta, 2009. 